\section{References}

1. Morrow AG, Reitz BA, Epstein SE, Henry WL, Conkle DM, Itscoitz SB, et al. Operative treatment in hypertrophic subaortic stenosis. Techniques, and the results of pre and postoperative assessments in 83 patients. Circulation. 1975;52:88-102.

2. Seeburger J, Borger MA, Falk V, Mohr FW. Gore-Tex loop implantation for mitral valve prolapse: the Leipzig loop technique. Op Tech Thorac Cardiovasc Surg. 2008;13:83-90.

3. Rankin JS, Binford RS, Johnston TS, Matthews JT, Alfery DD, McRae AT, et al. A new mitral valve repair strategy for hypertrophic obstructive cardiomyopathy. J Heart Valve Dis. 2008;17:642-7.
4. Kofflard MJ, van Herwerden LA, Waldstein DJ, Ruygrok P, Boersma E Taams MA, et al. Initial results of combined anterior mitral leaflet extension and myectomy in patients with obstructive hypertrophic cardiomyopathy. J Am Coll Cardiol. 1996;28:203-6.

5. Schoendube FA, Klues HG, Reith S, Flachskampf FA, Hanrath P, Messmer BJ Long-term clinical and echocardiographic follow-up after surgical correction of hypertrophic obstructive cardiomyopathy with extended myectomy and reconstruction of the subvalvular mitral apparatus. Circulation. 1995;92(9 Suppl): II122-7.

\title{
Surgical repair of aortopulmonary window associated with interrupted aortic arch: Long-term outcomes
}

\author{
Igor E. Konstantinov, $\mathrm{MD}, \mathrm{PhD}$, Norihiko Oka, $\mathrm{MD}, \mathrm{PhD}$, Yves d'Udekem, $\mathrm{MD}, \mathrm{PhD}$, and
}

Christian P. Brizard, MD, Melbourne, Australia

Association of aortopulmonary window (APW) with interrupted aortic arch (IAA) is very rare. Only $3.5 \%$ to $4.2 \%$ of patients with IAA have APW. ${ }^{1-3}$ Thus the cumulative experience with this combination of lesions is limited to isolated case reports. The largest multi-institutional study of 20 patients operated on from 1987 to 1997 demonstrated survival of $91 \%, 86 \%$, and $84 \%$ at 1,5 , and 10 years, respectively. ${ }^{2}$ Furthermore, competing risk analysis estimated that at 5 years

From the Department of Cardiac Surgery, Royal Children's Hospital, the Department of Paediatrics, University of Melbourne, and Murdoch Children's Research Institute, Melbourne, Australia.

Disclosures: None.

Received for publication Oct 5, 2009; revisions received Nov 13, 2009; accepted for publication Dec 28, 2009; available ahead of print April 5, 2010.

Address for reprints: Igor E. Konstantinov, MD, PhD, Royal Children's Hospital, Flemington Rd, Parkville, Victoria 6009, Australia (E-mail: igor.konstantinov@ rch.org.au).

J Thorac Cardiovasc Surg 2010;140:483-4

0022-5223/\$36.00

Crown Copyright (c) 2010 Published by Elsevier Inc. on behalf of The American Association for Thoracic Surgery

doi:10.1016/j.jtcvs.2009.12.043 after repair, 51\% had arch reintervention, $6 \%$ had pulmonary artery reintervention, and only $43 \%$ were alive without reintervention. ${ }^{2}$ Herein we report the long-term outcomes of 5 patients from a single institution and describe our aortic mobilization and advancement technique, which resulted in a low reintervention rate in this rare subgroup of patients.

\section{CLINICAL SUMMARY}

Cardiopulmonary bypass is established through a median sternotomy. Patients were cooled to a mean of $19^{\circ} \mathrm{C}$. Mean cardiopulmonary bypass time was 69 minutes. Mean circulatory arrest time was 27 minutes. Mean aortic cross-clamp time was 40 minutes. The aortic arch, APW, and descending aorta were dissected (Figure 1, $A$ ). The descending aorta was extensively mobilized, and all ductal tissues were removed during circulatory arrest with cerebral perfusion (Figure 1, $B)$. The thick-walled ductal tissues were resected until the normal thin wall of the aorta appeared. The extent of the mobilization of the descending aorta was evolved to our currently used technique, in which at least 3 pairs of intercostal arteries are divided to ensure proper mobilization of the
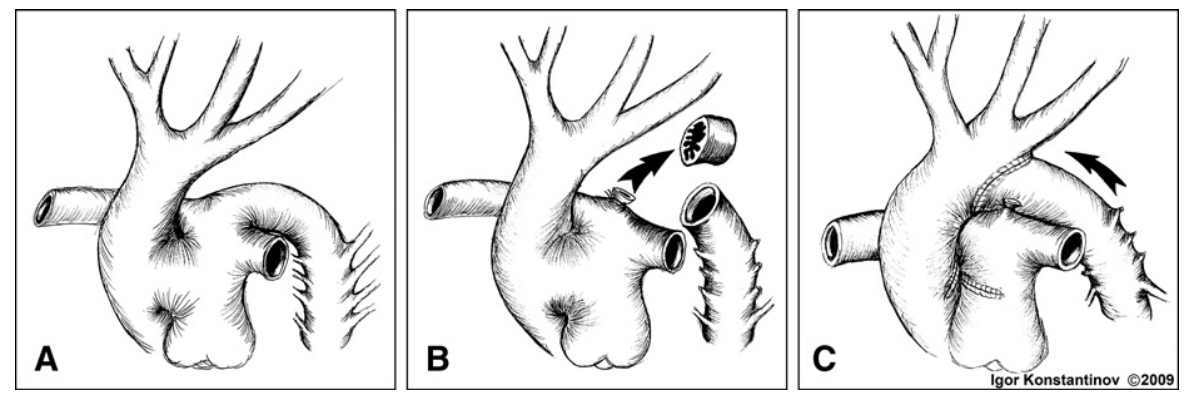

FIGURE 1. Aortic mobilization and advancement. A, Aortopulmonary window with interrupted aortic arch, type A. B, All ductal tissue is removed, and 3 pairs of intercostal arteries are divided to ensure adequate mobilization of the descending aorta. C, The descending aorta is anastomosed into the arch in an endto-side fashion. The aortopulmonary window is transected, and the resulting defects are closed individually with direct sutures. 
TABLE 1. Patients' characteristics

\begin{tabular}{lcclccccc}
\hline Patient no. & Year of repair & Age $(\mathbf{d})$ & Sex & Weight $(\mathbf{k g})$ & IAA type & APW type & Follow-up period (y) & Reintervention \\
\hline 1 & 1985 & 3 & F & 2.3 & A & 3 & 24.1 & No \\
2 & 1986 & 10 & F & 2.2 & B & 1 & 22.4 & Yes \\
3 & 1987 & 13 & M & 2.2 & A & 1 & 1.8 & No \\
4 & 1993 & 10 & M & 2.9 & A & 1 & No \\
5 & 2006 & 6 & M & 2.9 & A & 1 & No \\
\hline
\end{tabular}

$I A A$, interrupted aortic arch; $A P W$, aortopulmonary window.

descending aorta. The descending aorta is then anastomosed into the aortic arch in an end-to-side fashion, the APW is opened, and the aorta and pulmonary artery are closed individually with direct sutures (Figure 1,C). One patient with IAA type B had arch repair through the thoracotomy first and APW repair through sternotomy 7 days later.

Between 1985 and 2007, 112 patients had surgical repair of IAA, ${ }^{3}$ and 42 patients had surgical treatment of APW. Five of these patients (3-13 days of age; mean age, 8.4 days) had an association of both anomalies (4.5\% [5/112] of patients with IAA and $11.9 \%$ [5/42] of patients with APW). The anatomy was described according to the Cerolia and Patton classification for IAA ${ }^{4}$ and the Richardson classification for APW. ${ }^{5}$ The IAA was type A in 4 patients and type B in 1 patient. The APW was type I in 4 patients and type III in 1 patient (Table 1). All patients had simultaneous IAA and APW repair. The follow-up ranged from 3.4 to 24.1 years (mean, $17.6 \pm 8.4$ years). There were no hospital deaths. One patient required balloon dilatation of the aortic arch at 13 years after repair.

\section{DISCUSSION}

Because of the rarity of patients with the combination of both APW and IAA, the world's surgical experience with these combined anomalies is limited. Yet these patients often present during the neonatal period, have low birth weight, might have signs of pulmonary overcirculation and systemic malperfusion, and require urgent surgical intervention. In fact, all 5 of our patients underwent surgical intervention within 3 weeks after birth and had a body weight of less than $3 \mathrm{~kg}$ at the time of the operation. Although operative mortality of the patients with IAA has decreased significantly during recent decades, the long-term follow-up of patients with APW and IAA is limited to isolated case reports. ${ }^{2}$ Four of our patients had at least 15 years of follow-up. One of them required a transcatheter balloon dilatation of the stenosis at the site of arch anastomosis at 13 years after the repair. This patient had a type B IAA, which is known as a risk factor of reintervention for IAA. ${ }^{1}$ Thus freedom from aortic arch reintervention was $75 \%$ (3/4 patients) at 15 years. None of our patients required reintervention for any other cause.

We believe that extensive mobilization of the descending aorta and meticulous resection of all ductal tissue is a key element of good long-term outcome. A tension-free advancement of the properly mobilized descending aorta appears to maintain an unobstructed aortic arch and prevents compression of the branch pulmonary arteries and bronchi long-term.

\section{References}

1. McCrindle BW, Tchervenkov CI, Konstantinov IE, Williams WG, Neirotti RA, Jacobs ML, Blackstone EH. Risk factors associated with mortality and reinterventions in 472 neonates with interrupted aortic arch: a congenital heart surgeons society study. J Thorac Cardiovasc Surg. 2005;129:343-50.

2. Konstantinov IE, Karamlou T, Williams WG, Quaegebeur JM, del Nido PJ, Spray TL, et al. Surgical management of aortopulmonary window associated with interrupted aortic arch: a Congenital Heart Surgeons Society study. $J$ Thorac Cardiovasc Surg. 2006;131:1136-41.

3. Hussein A, Iyengar AJ, Jones B, Donath SM, Konstantinov IE, Grigg LE, et al. Twenty-three years of single-stage end-to-side anastomosis repair of interrupted aortic arches. J Thorac Cardiovasc Surg. 2010;139:942-9.

4. Cerolia GC, Patton RB. Congenital absence of the aortic arch. Am Heart J. 1959; 58:407-13.

5. Richardson JV, Doty DB, Rossi NP, Ehrenhaft JL. The spectrum of anomalies of aortopulmonary septation. J Thorac Cardiovasc Surg. 1979;78:21-7. 